\title{
Wykorzystanie numerycznych modeli terenu do generowania systemu drenażu powierzchniowego, funkcjonującego podczas opadów nawalnych Podstawy metodyczne na podstawie studium przypadku zlewni Zalasówki (Pogórze Ciężkowickie)
}

\author{
Use of digital terrain models to generate the surface drainage network \\ functioning during heavy rainfall \\ Methodological aspects based on the Zalasówka catchment (Ciężkowickie foothills)
}

\author{
RAFAŁ KROCZAK, TOMASZ BRYNDAL \\ Instytut Geografii, Uniwersytet Pedagogiczny w Krakowie \\ 30-084 Kraków, ul. Podchorążych 2; kroraf@up.krakow.pl
}

Zarys treści. W poznaniu mechanizmów formowania się powodzi błyskawicznych istotna jest informacja o parametrach systemu drenażu powierzchniowego. System ten składa się z elementów pochodzenia naturalnego (doliny) oraz antropogenicznego (np. drogi, rowy, bruzdy itp.). W artykule dokonano oceny numerycznych modeli terenu (NMT) dostępnych dla obszaru Polski, pod kątem ich przydatności do generowania systemu drenażu powierzchniowego, jaki funkcjonuje podczas opadów nawalnych w małych zlewniach karpackich. Opracowano metodyczne podstawy i zaproponowano procedurę, która na podstawie analizy NMT pozwala wygenerować tego rodzaju system. Zastosowanie procedury pozwoliło poznać „rzeczywiste rozmiary” systemu drenażu powierzchniowego, który przyczynia się do generowania powodzi błyskawicznych. Stosując tzw. analizę hortonowską scharakteryzowano różnice jakie występują w przypadku uwzględniania antropogenicznych elementów modyfikujących naturalny system rzeczny w zlewni.

Słowa kluczowe: numeryczny model terenu, system drenażu, powódź błyskawiczna, Karpaty.

\section{Wstęp}

Powodzie błyskawiczne formowane są w wyniku krótkotrwałych i intensywnych opadów deszczu. W Polsce zwykle występują one w zlewniach o powierzchni mniejszej od $40 \mathrm{~km}^{2}$ (Bryndal, 2014). Istotny wpływ na formowanie fal wezbraniowych ma skoncentrowany spływ powierzchniowy, który występuje w naturalnych (dna dolin) oraz antropogenicznych obniżeniach terenu (drogi, 
rowy, bruzdy polne itp.). Ocenia się, że gęstość systemu drenażu powierzchniowego będącego skutkiem działalności człowieka w małych zlewniach karpackich może osiągnąć wartość $19 \mathrm{~km} \cdot \mathrm{km}^{-2}$, podczas gdy gęstość sieci rzecznej w Karpatach z reguły nie przekracza 2,6 km·km ${ }^{-2}$ (Soja, 2002; Bryndal, 2014; Kroczak i inni, 2016). Podczas opadów nawalnych funkcjonuje jeden system złożony z elementów pochodzenia naturalnego i antropogenicznego. Wyznaczenie linii, którymi woda spływa w sposób zorganizowany jest istotne w aspekcie poznania „rzeczywistych rozmiarów” systemu drenażu powierzchniowego, jaki funkcjonuje podczas opadów nawalnych w zlewni. To z kolei przyczynia się do lepszego poznania mechanizmów formowania się powodzi błyskawicznych w małych zlewniach (Kroczak i Bryndal, 2015).

Jedną z metod pozwalających wygenerować system drenażu powierzchniowego jest analiza numerycznych modeli terenu (NMT) przy wykorzystaniu modułów oprogramowania GIS (Geographic Information Systems) wspomagających analizy hydrologiczne. W Polsce pierwsze modele terenu dla dużych obszarów opracowano na początku lat 1990. (Pyka, 1994). Zmiany jakości NMT polegają na zmniejszaniu błędu zapisu pionowego i poziomego oraz znaczącym wzroście rozdzielczości, co znacząco poszerza wykorzystanie NMT w analizach hydrologicznych.

Celem pracy jest:

1) charakterystyka oraz ocena przydatności NMT, do generowania systemu drenażu powierzchniowego, funkcjonującego podczas opadów nawalnych w małych zlewniach karpackich,

2) zaprezentowanie metodycznych podstaw procedury generowania systemu drenażu powierzchniowego uwzględniającego elementy pochodzenia naturalnego i antropogenicznego,

3) analiza „rzeczywistych rozmiarów” systemu drenażu powierzchniowego, funkcjonującego podczas opadów nawalnych w zlewni, oraz ocena różnic w systemie drenażu jakie występują w przypadku uwzględniania antropogenicznych elementów modyfikujących naturalny system rzeczny w zlewni.

\section{Materiały i metody}

Charakterystyki NMT oraz ich oceny do generowania systemu drenażu powierzchniowego dokonano na podstawie analizy parametrów modeli tj. rozdzielczość, błąd zapisu poziomego i pionowego. Uwzględniono popularne NMT dostępne dla obszaru Polski. Informacje te pozyskano z literatury oraz metadanych opisujących poszczególne NMT. Wybrano NMT o parametrach odpowiednich do wygenerowania sieci drenażu powierzchniowego zawierającego elementy, które funkcjonują w zlewni podczas opadów nawalnych.

System drenażu powierzchniowego wyznaczono zgodnie z powszechnie przyjętą procedurą prowadzenia analiz hydrologicznych przy wykorzystaniu opro- 
gramowania GIS. Wykorzystanie tej procedury do realizacji celów postawionych w pracy wymagało opracowania metodyki optymalizacji NMT. Jej celem było uzyskanie jak największej zgodności w przebiegu linii będących odzwierciedleniem systemu drenażu powierzchniowego na warstwie wygenerowanej z NMT z ciekami, które funkcjonowały w zlewni podczas opadów nawalnych. Aby ułatwić czytelnikowi analizę etapów postępowania badawczego, zagadnienia związane z optymalizacją NMT, oraz procedurą generowania systemu drenażu powierzchniowego, zostały szczegółowo omówione w dalszej części tekstu.

Zastosowanie procedury pozwoliło ocenić „rzeczywiste rozmiary” systemu drenażu powierzchniowego, jaki funkcjonuje podczas opadów nawalnych w małych zlewniach karpackich. Oceny różnic, jakie występują w przypadku uwzględniania antropogenicznych elementów modyfikujących naturalny system rzeczny w zlewni dokonano przeprowadzając tzw. analizę hortonowską (Horton, 1945; Schumm, 1956), oraz porównując gęstość sieci rzecznej $\left(\mathrm{km} \cdot \mathrm{km}^{-2}\right)$ z gęstością sieci drenażu powierzchniowego.

\section{Teren badań}

Badania przeprowadzono w zlewni Zalasówki (9,2 km²), która jest położona na Pogórzu Ciężkowickim (ryc. 1). Dominują w niej stoki o nachyleniu 5-15², zajmując 60\% powierzchni zlewni. Gęstość sieci rzecznej wynosi $1,5 \mathrm{~km} \cdot \mathrm{km}^{-2}$. Jest to typowa pogórska zlewnia rolnicza. Ponad 3/4 powierzchni zlewni zajmują użytki rolne. Rozwój osadnictwa oraz późniejsze zmiany struktury własności spowodowały, że działki rolne są silnie rozdrobnione. Dzięki temu wykształciła się rozbudowana sieć dróg polnych i rowów. Wybór tej zlewni był konsekwencją wcześniejszych badań, które dostarczyły podstawowego materiału dokumentacyjnego, związanego z formowaniem się spływu powierzchniowego podczas opadu nawalnego.

\section{Wyniki}

\section{Przegląd ogólnodostępnych numerycznych modeli terenu dostępnych dla obszaru Polski}

W badaniach hydrologicznych powszechnie wykorzystuje się kilka NMT. Różnią się one zasięgiem (globalny, regionalny, lokalny), oraz parametrami (rozdzielczość, błąd zapisu pionowego i poziomego itd.). Poniżej przeprowadzono krótką charakterystykę NMT, które najczęściej stosuje się w badaniach hydrologicznych, oraz dokonano oceny ich przydatności do generowania systemu drenażu powierzchniowego, funkcjonującego podczas opadów nawalnych w małych zlewniach karpackich. 


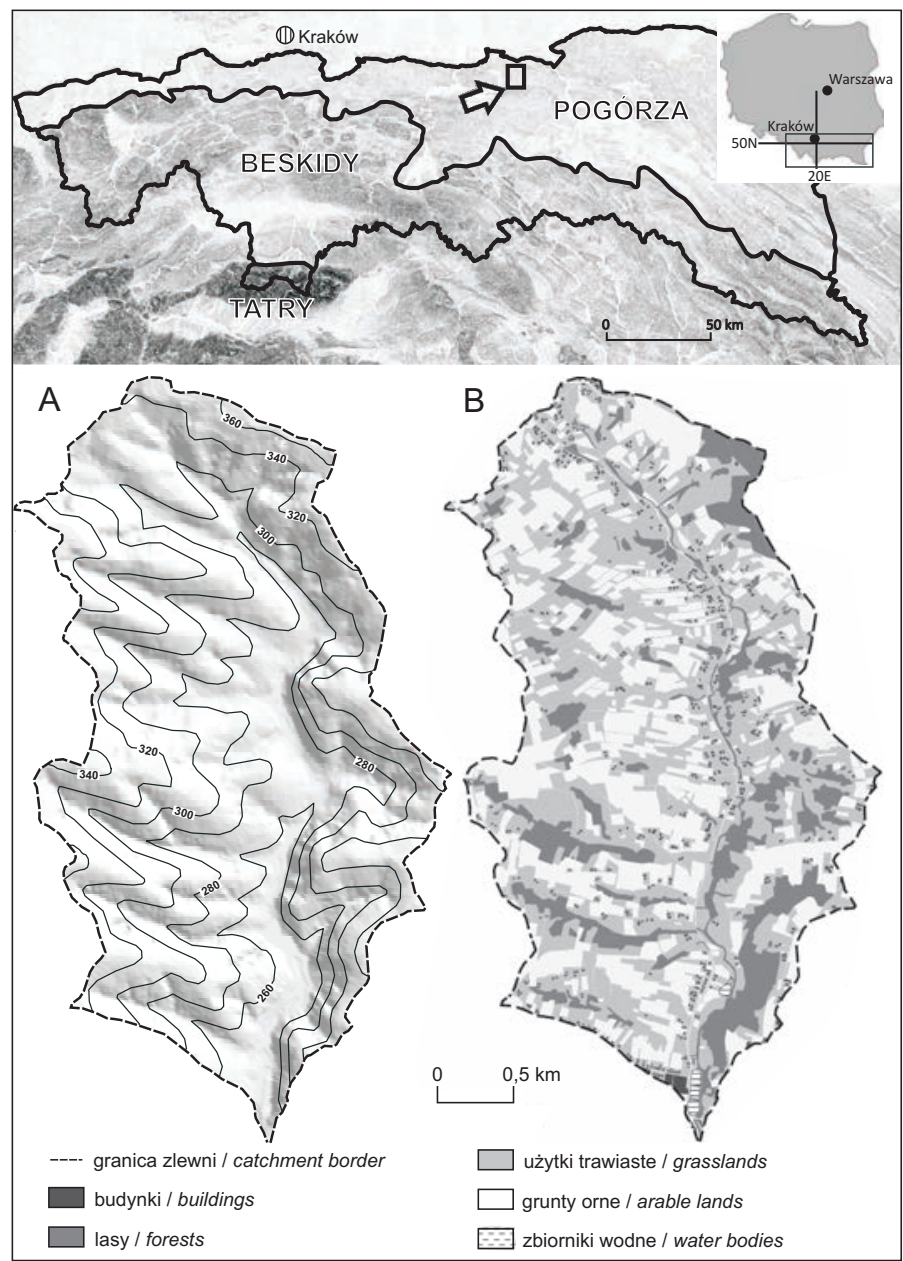

Ryc. 1. Położenie, rzeźba - A oraz struktura użytkowania - B zlewni Zalasówki. Location and relief - A and structure of land cover - B, in the Zalasówka catchment Źródło podkładu / Basemap source: NMT SRTM

\section{Modele o zasięgu globalnym}

W badaniach hydrologicznych najczęściej wykorzystuje się dwa modele: SRTM (Shuttle Radar Topography Mission), oraz ASTER (Advanced Spaceborne Thermal Emission and Reflection Radiometer). Pierwszy z nich, to interferometryczny model terenu obejmujący około 80\% lądów. Dla Polski udostępniane są dane o rozdzielczości poziomej 3", czyli 60-65×90 m (Śleszyński, 2009). Model ASTER został wykonany na podstawie zdjęć z bliskiej podczerwieni (VNIR), 
z danych zebranych przez skaner Aster umieszczony na satelicie Terra. Generowanie numerycznego modelu terenu odbywa się metodą stereoskopową w sposób automatyczny, w czym upatruje się źródeł błędów. Teren przedstawiony jest w formie danych rastrowych o rozmiarze 1" czyli 30x30m. Dane z obydwu zasobów przedstawiają wartości pionowe wraz z pokryciem terenu (bez niwelacji do poziomu gruntu), co znacząco ogranicza ich zastosowanie w badaniach hydrologicznych małych zlewni. Większa rozdzielczość modelu ASTER nie poprawia jego efektywnego wykorzystania w analizach hydrologicznych, co więcej, błędy przy wyznaczaniu sieci drenażu lub granic zlewni z modelu ASTER mogą być większe niż z modelu SRTM (Przybyła i Pyszny, 2013).

\section{Modele terenu o zasięgu regionalnym i lokalnym}

Pierwszą grupę stanowią modele, generowane z poziomic. W Polsce jest to model DTED 2 (Digital Terrain Elevation Data Level 2) opracowany na podstawie digitalizacji poziomic z topograficznych map wojskowych w skali 1:50 000. Ze względu na wielkość rastra $(30 \mathrm{~m})$, przy dokładności pionowej $20 \mathrm{~m}$, użyteczność tego zasobu w analizach hydrologicznych jest zbliżona do modeli ASTER i SRTM. Lepsze parametry ma NMT wykonany jako komponent TBD (Topograficznej Bazy Danych). Został on opracowany metodą fotogrametryczną na podstawie zdjęć lotniczych z uwzględnieniem linii strukturalnych. Model charakteryzuje wysoka precyzja na terenach otwartych, natomiast na obszarach pokrytych gęstą roślinnością jego jakość gwałtownie maleje. Średniokwadratowy błąd dla większości opracowanych obszarów (RMSE) nie przekracza $1 \mathrm{~m}$ (Olszewski i inni, 2008). Podobne parametry (RMSE = 0,8 m) ma model wykonany w ramach SMOK-u (System Monitorowania i Osłony Kraju). Ostatnie dwa modele mogą być wykorzystywane w prowadzeniu ogólnych analiz hydrologicznych w małych zlewniach (np. obliczania parametrów fizjograficznych), jednakże mają ograniczone zastosowanie w szczegółowych analizach, w tym do generowania i analizy elementów systemu drenażu powierzchniowego pochodzenia antropogenicznego.

Warto wspomnieć o NMT, które nie są ujęte w żadnym krajowym zasobie. Są to modele terenu wykonywane przez badaczy na podstawie digitalizacji poziomic (m.in. Prokop, 2007; Gudowicz, 2008; Kroczak, 2010; Bucała, 2012; Wiejaczka i inni, 2012; Wałek, 2013; Jaskulski i Szmidt, 2015). Źródłem danych jest najczęściej mapa topograficzna w skali 1:10 000. Dokładność poziomą i pionową determinuje dokładność rysunku poziomicowego, a rozdzielczość takich danych definiowana jest przez źródło. Dla mapy w skali 1:10 000 rozdzielczość nie powinna być mniejsza od 5x5 m (Urbański, 2008). Modele te pozwalają na uwzględnienie w systemie drenażu powierzchniowego niektórych elementów pochodzenia antropogenicznego np. sieci dróg (Kroczak, 2010; Kroczak i Bryndal, 2015). 
W ostatnich kilku latach nastąpił dynamiczny rozwój NMT generowanych z tzw. chmury punktów pochodzącej z laserowego skanowania powierzchni terenu, ogólnie nazywanych danymi LiDAR-owymi (Light Detection And Ranging). Do analiz hydrologicznych szczególnie przydatne są dane pozyskiwane w wyniku zastosowania techniki ALS (Airborne Laser Scaning). Umożliwia ona pozyskanie bardzo dokładnych danych o powierzchni terenu dla dużych obszarów. Obecnie dane pozyskane z ALS są najdokładniejszym jednolitym źródłem danych wejściowych wykonanych dla dużych obszarów i stopniowo wypierają wcześniejsze zasoby, zwłaszcza NMT opracowane na bazie wielkoskalowych zdjęć lotniczych (Kurczyński i Bakuła, 2013). Dane LiDAR pochodzące z ALS gwarantują wysoką jakość i udostępniane są w formie sklasyfikowanej chmury punktów z dokładnością pionową o błędzie poniżej 0,15 $\mathrm{m}$ w standardzie I (obszary pozamiejskie $4-6 \mathrm{pkt} \cdot \mathrm{m}^{-2}$ ) i poniżej 0,10 m w standardzie II (obszary miejskie 12-14 $\mathrm{pkt} \cdot \mathrm{m}^{-2}$ ). Co ważne, rozdzielczość tego rodzaju danych (gęstość punktów na $\mathrm{m}^{-2}$ ) nie jest standaryzowana. Spośród krajów europejskich np. Niemcy i Holandia posiadają dane LiDAR-owe o zbliżonych parametrach do tych pozyskanych w ramach realizacji projektu ISOK w Polsce. Inne jednak, jak Szwecja, Szwajcaria czy Dania, dysponują danymi o rozdzielczości nawet 10-krotnie mniejszej (Kurczyński i Bakuła, 2013).

Trzeba również wspomnieć o danych LiDAR-owych pozyskiwanych z poziomu terenu TLS (Terrestrial Laser Scanning) czy z niskich i krótkich nalotów wykonywanych przy użyciu samolotów bezzałogowych UAV (Unmanned Aerial Vehicle). Chmura punktów pozyskana tą metodą ma od kilkuset punktów na $\mathrm{m}^{2}$, jednakże opracowanie bazy danych, nawet dla małej zlewni, jest bardzo praco- i czasochłonne. Metoda ta doskonale sprawdza się w monitorowaniu małych form rzeźby terenu, takich jak osuwiska (Cebulski, 2015) czy obiekty cenne przyrodniczo (Wężyk i inni, 2015). Warto w tym miejscu zwrócić uwagę na szybko rozwijającą się, alternatywą dla TLS-u technologię SfM (Structure from Motion). Polega ona na tworzeniu chmur punktów (a w konsekwencji modeli przestrzennych) z zasobu zdjęć obejmujących cały badany obiekt (formę) i mających duże wzajemne pokrycie. Metoda ta, podobnie jak stereowizja, bazuje na punktach wspólnych, a rozdzielczość finalna chmury punktów jest wypadkową rozdzielczości i liczby wykonanych zdjęć. SfM wykorzystywany jest w Polsce np. do identyfikacji przekształceń antropogenicznych w korytach rzecznych (Witek i inni, 2013).

Podsumowując można stwierdzić, że sieć drenażu powierzchniowego w małych zlewniach najlepiej jest wyznaczyć korzystając z NMT generowanego z danych LiDAR-owych pochodzących z lotniczego skaningu ALS. Dlatego w dalszych analizach był to podstawowy zasób danych. 


\section{Metodyczne podstawy procedury generowania systemu drenażu powierzchniowego}

Do wyznaczania linii spływu powierzchniowego zastosowano powszechnie przyjętą procedurę, zaimplementowaną w programach GIS. Wykorzystanie tej procedury wymagało jednak opracowania dwóch zagadnień:

1) metodyki optymalizacji NMT, oraz

2) doboru algorytmu do generowania systemu drenażu powierzchniowego, który pozwala uwzględnić elementy pochodzenia antropogenicznego (drogi, bruzdy itp.).

\section{Podstawy optymalizacji numerycznego modelu terenu}

Numeryczny model terenu generowany z danych LiDAR zapewnia dokładne odwzorowanie powierzchni terenu w zlewni, uwidoczniając bardzo drobne formy, np. drogi (w tym polne w różnych stadiach rozwoju), miedze śródpolne, terasy rolne, bruzdy, kanały, rowy przydrożne itp. Należy jednak podkreślić, że tego typu NMT nie jest pozbawiony wad (Affek, 2014). Powierzchnia gruntu zawiera takie elementy jak mosty, przepusty, a nawet składowiska odpadów (gałęzie, chwasty usuwane z pól zalegające w obniżeniach), które powodują, że wygenerowany system drenażu powierzchniowego różni się od tego, który funkcjonuje w terenie. Przed przystąpieniem do analiz hydrologicznych, konieczne jest zoptymalizowanie NMT. Proces ten polega na: (1) identyfikacji (badania terenowe, analizy zdjęć lotniczych) i (2) „usunięciu” (poprzez „wypalenie”) przeszkód (np. mosty, przepusty, nasypy, wały itp.), które zaburzają rzeczywisty kierunek spływu wód. W procedurze wykorzystano algorytm „wypalania” cieków w NMT. Algorytm ten był jednym z pierwszych etapów stosowania narzędzi GIS w hydrologii (Moore i inni, 1991). Jego stosowanie było konieczne, gdyż sieć rzek generowana na podstawie NMT budowanych z małoskalowych map topograficznych była słabo czytelna, co utrudniało prowadzenie analiz hydrologicznych. W NMT budowanych z wielkoskalowych map topograficznych „wypalanie” umożliwiło uwzględnienie znacznie mniejszych form niż koryta rzeczne, np. sieci wcięć drogowych, nasypów drogowych itp. (Kroczak, 2010). Warto jednak podkreślić, że, bazując na NMT budowanych z map topograficznych (głównie 1:10 000) nie ma możliwości ujęcia form mniejszych niż wielkość podstawowego rastra (najczęściej 5m). Proces optymalizacji NMT jest czaso- i pracochłonny, ponieważ parametry opisujące przeszkody (np. przepust, most) muszą być pozyskane w wyniku badań terenowych. Nawet wykorzystanie baz typu BDOT, w których w formie atrybutów znajdują się informacje opisujące drobne formy (np. kanały, przepusty itp.), nie dają zadowalających wyników.

W procesie optymalizacji NMT zaproponowano postępowanie wg następujących punktów. 
1) zaznaczenie przeszkody (digitalizacja - dane liniowe wektorowe; umieszczenie linii w osi przeszkody),

2) opisanie przeszkody (każdego wektora) czterema atrybutami (ryc. 2),

a) „bufor” opisuje odległość w linii prostej od osi formy do jej granicy,

b) „wcięcie” opisuje głębokość formy,

c) „koryto”, które opisuje wartość wcięcia samego koryta cieku (ryc. 2A). Atrybut ten pełni rolę pomocniczą i pozwala na „pogłębienie” formy o wartość większą niż wynika to z wartości atrybutów „wcięcie” i „bufor” (ryc. 2B). Pozwala on utrzymać „ciągłość” sieci odwadniającej, zgodnie z stanem faktycznym obserwowanym $\mathrm{w}$ terenie.

d) „szerokość”, jest również atrybutem pomocniczym, który określa rozmiar przeszkody w sytuacji, kiedy szerokość formy jest znacznie większa niż bok rastra budującego NMT, oraz usuwana przeszkoda ma pionowe ściany (np. szeroki most). Wówczas „wypalenie” takiej formy odbywa się poprzez połączenie atrybutów „koryto” i „szerokość” (ryc. 2C). W takiej sytuacji, wcięcie samego koryta wymaga powtórzenia procedury „wypalania” dla samego atrybutu „koryto” (ryc. 2D).

3) modyfikacji NMT poprzez tzw. „wypalenie” w powierzchni NMT przebiegu wektora opisującego przeszkodę, z uwzględnieniem zdefiniowanych dla niego atrybutów (ryc. 3). Wymienione operacje realizowane są przez moduły oprogramowania GIS.

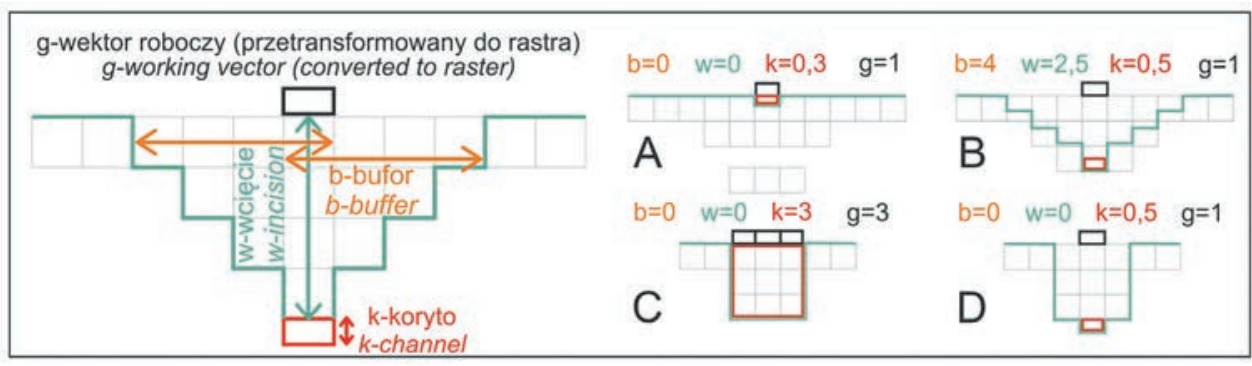

Ryc. 2. Założenia w algorytmie optymalizacji NMT w nawiązaniu do różnych typów przeszkód

(b - bufor [m], w - wcięcie [m], k - koryto [m], g - liczba rastrów opisujących szerokość przeszkody)

Underlying assumptions for the DTM optimisation procedure in relation to different types of terrain obstacles (buffer [m], w - incision [m], k - channel [m], g - number of rasters describing obstacle width)

Opracowanie własne, podobnie pozostałe ryciny / Authors' own elaboration, as with the remaining figures.

Po procesie optymalizacji otrzymuje się NMT, który można traktować jako podstawową bazę do prowadzenia analiz hydrologicznych, mających na celu wyznaczenie system drenażu powierzchniowego złożonego z elementów pocho- 


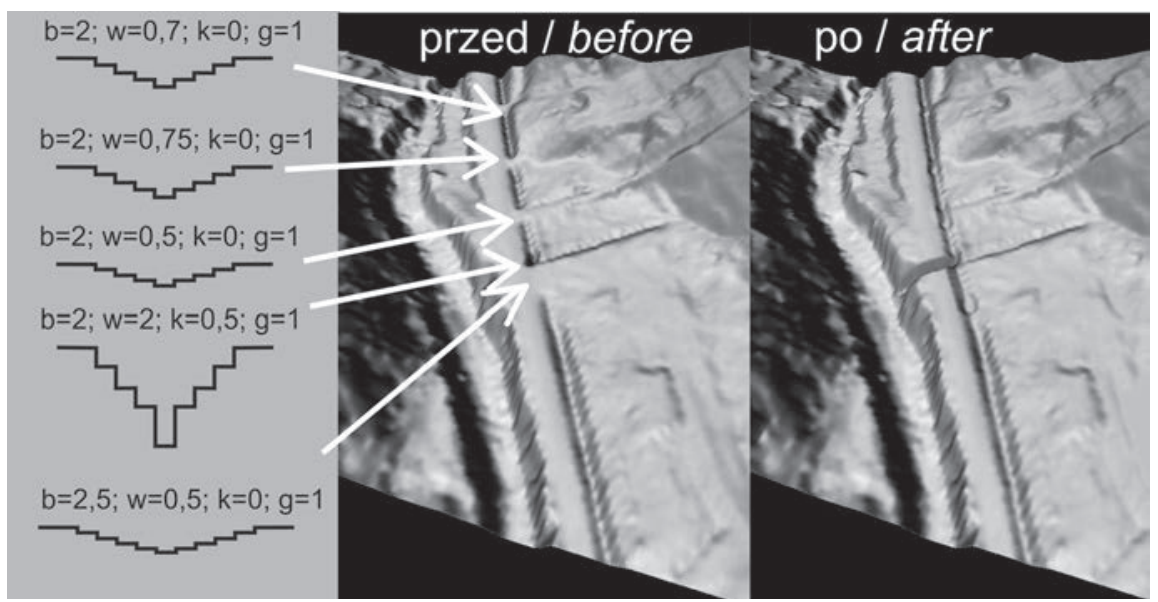

Ryc. 3. Numeryczny model terenu przed i po optymalizacji przeprowadzonej według algorytmu prezentowanego na rycinie 2

Digital terrain model before and after optimisation process in line with algorithm presented in Fig. 2

dzenia naturalnego, oraz antropogenicznego. Procedura optymalizacji NMT jest czasochłonna i pracochłonna, a dotychczasowe próby zautomatyzowania tego procesu nie dały zadowalających efektów. Duży nakład pracy konieczny na tym etapie badań powoduje, że powszechne używanie tej procedury jest na razie ograniczone.

\section{Dobór algorytmu pozwalającego wygenerować system drenażu powierzchniowego}

W modułach do analiz hydrologicznych implementowanych w oprogramowaniu GIS znajduje się szereg algorytmów pozwalających wyznaczyć sieć drenażu powierzchniowego. Prowadząc analizy z ich wykorzystaniem, kluczowym elementem jest wybór algorytmu odpowiednio dobranego do fizycznogeograficznej charakterystyki badanej zlewni (Jasiewicz, 2010; Płaczkowska i inni, 2015), a pozwalającego osiągnąć zamierzony cel badań. Jednym z najprostszych, najczęściej wykorzystywanych i powszechnie implementowanych w modułach do analiz hydrologicznych jest algorytm o nazwie D8. Jego twórcy (O'Callaghan i Mark, 1984) analizując modele terenu, z trzech poligonów badawczych zlokalizowanych w Stanach Zjednoczonych i Australii wyszli z założenia, że zorganizowany spływ rozpoczyna się po przekroczeniu predefiniowanej wartości progowej. Punktem wyjścia jest określenie w każdej macierzy elementarnej (3x3 rastry) różnicy wysokości pomiędzy komórką środkową a każdą z ośmiu komórek otaczających. Spływ kierowany jest od komórki środkowej w stronę komórki, 
w stosunku do której obliczony został największy spadek terenu. Tym samym miejsce inicjacji linii odpływu skoncentrowanego jest wielokrotnością predefiniowanej powierzchni obszaru położnego powyżej. W praktyce oznacza to określenie liczby rastrów, z których odpływ jest przejmowany i odprowadzany przez dany raster, np. zamykający zlewnie cząstkowe. Algorytm D8 był rozbudowywany, a jego modyfikacjami są m.in. D8-LTD, MFD - Multiple Flow Direction, Random eight-node, DEMON - Digital Elevation Model Networks (Turcotte i inni, 2001, Hengl i Router, 2008; Jasiewicz, 2010). Mając na uwadze cele postawione w niniejszej pracy, wykorzystano jego pierwotną wersję. Zaletą algorytmu D8 jest identyfikacja w każdej macierzy elementarnej tylko jednego kierunku spływu. W obszarach o małych deniwelacjach może to prowadzić do generowania linii równoległych, co jest często postrzegane jako ograniczenie w jego stosowaniu. Przy wysokiej rozdzielczości i dokładności modelu NMT generowanego z danych ALS algorytm ten pozwala na wyznaczanie linii odpływu, które uwzględniają małe formy rzeźby terenu (bruzdy, rzędy upraw i inne elementy linijne), funkcjonujące podczas opadów nawalnych jako cieki epizodyczne. Ponadto algorytm ten jest z powodzeniem wykorzystywany do analiz hydrologicznych bazujących na modelach terenu o różnej dokładności (Persendt i Gomez, 2015), co umożliwia porównywalność wyników.

\section{Wyznaczanie wartości progowych formowania się skoncentrowanego spływu powierzchniowego}

W procesie generowania systemu drenażu powierzchniowego przy zastosowaniu NMT oraz algorytmu D8, podstawowym zagadnieniem jest odpowiedź na pytanie, gdzie rozpoczyna się spływ skoncentrowany. Miejsce takie można interpretować w kontekście formowania się pierwszego ogniwa systemu drenażu powierzchniowego (head channel). Jak wspomniano, w algorytmie D8 miejsce inicjacji linii spływu skoncentrowanego jest wielokrotnością predefiniowanej powierzchni obszaru położnego powyżej. Wartość tę należy ustalić i podać jako jeden z parametrów w module analizy hydrologicznej oprogramowania GIS. W niniejszej pracy zastosowano podejście, w którym:

1) przeprowadzono kartowanie linii skoncentrowanego spływu powierzchniowego i wyznaczono miejsca, w których zaczął się on formować,

2) dla wyznaczonych miejsc obliczono powierzchnię zlewni cząstkowych (head channel), które następnie traktowano jako wartości progowe przy generowaniu systemu drenażu powierzchniowego.

Kartowanie przeprowadzono po opadzie nawalnym, który wystąpił w nocy z 26 na 27 czerwca 2009 r. i spowodował powodzie błyskawiczne w zlewni Wątoku i Zalasówki (Bryndal i inni, 2010). Opad nawalny trwał od 19:30 do 23:50 czasu lokalnego. Natężenie opadu osiągało $12 \mathrm{~mm} \cdot 10 \mathrm{~min}^{-1}$, dając sumę ponad $30 \mathrm{~mm}$; wartość ta jest uważana za progową przy generowaniu powodzi błyska- 
wicznych (Lorenc i inni, 2012). Podczas badań terenowych skartowano linie, którymi woda płynęła w sposób zorganizowany, oraz wyznaczono współrzędne miejsc, w których rozpoczynał się spływ skoncentrowany. Uwzględniono różne typy pokrycia terenu (grunty orne - różne formy użytkowania, użytki zielone, drogi), zlokalizowane na stokach o zróżnicowanym nachyleniu (2-10). Czynniki te istotnie wpływają na tempo formowania spływu powierzchniowego (Gil, 1998). Następnie na podstawie analizy NMT obliczono powierzchnię tych zlewni. Ujęcie takie pozwala powiązać miejsce formowania się skoncentrowanego spływu z parametrami zlewni elementarnej, takimi jak powierzchnia, nachylenie, użytkowanie terenu czy indeksy topograficzne (Julian i inni, 2012; Płaczkowska i inni, 2015).

\section{Zastosowanie procedury do generowania systemu drenażu powierzchniowego w zlewni Zalasówki}

Miejsca, w których obserwowano formowanie spływu skoncentrowanego po opadzie z 26 czerwca 2009 r. przedstawiono na rycinie 4. Tabela 1 prezentuje średnią powierzchnię zlewni, po przekroczeniu której dochodziło do uformowania skoncentrowanego spływu powierzchniowego. Na użytkach trawiastych wyniosła ona 0,31 ha (ryc. 4B), a na drogach polnych 0,25 ha. W drugim przypadku, ze względu na prostopadły przebieg dróg względem nachylenia stoku, obszarem alimentacyjnym była powierzchnia drogi i przyległych zboczy wąwozów drogowych (ryc. 4A, C, D). Na gruntach ornych pozbawionych roślinności (ryc. 4E), skoncentrowany spływ powierzchniowy wystąpił w zlewni o powierzchni zlewni 0,07 ha. Na gruntach z uprawami zbożowymi i rzędowymi spływ skoncentrowany uformował się w bruzdach ornych (ryc. 4A), a powierzchnia zlewni elementarnej wyniosła 0,52 ha. Zmiany użytkowania gruntów ornych związane z płodozmianem, podobne warunki formowania spływu powierzchniowego na gruntach ornych podczas opadów nawalnych (Gil, 1999) oraz możliwości pozyskania danych pozwalających w ujęciu rocznym analizować przestrzenny roz-

Tabela 1. Średnia powierzchnia zlewni, po przekroczeniu której dochodziło do uformowania skoncentrowanego spływu powierzchniowego

Mean catchment area, where concentrated flow was generated

\begin{tabular}{|l|c|c|}
\hline \multicolumn{1}{|c|}{$\begin{array}{c}\text { Typ użytkowania } \\
\text { Type of land use }\end{array}$} & $\begin{array}{c}\text { Liczba stanowisk } \\
\text { Number of places }\end{array}$ & $\begin{array}{c}\text { Sean catchments area } \\
\text { (ha) }\end{array}$ \\
\hline Użytek zielony & 5 & 0,31 \\
Droga polna & 5 & 0,25 \\
Grunt rolny & 6 & 0,24 \\
\hline
\end{tabular}

Opracowanie własne / Authors' own study. 
kład upraw, były przesłankami do uśrednienia wyników. Średnia wartość obliczona dla gruntów rolnych wyniosła 0,24 ha. Wartości te uznano za progowe przy wyznaczaniu systemu drenażu powierzchniowego. Obserwacje i obliczenia poczynione w górnej części ekstrapolowano na całą zlewnie Zalasówki. Na podstawie mapy użytkowania (ryc. 1) sporządzono „mapę tarcia”, na której typom pokrycia terenu przypisano atrybut określający minimalną powierzchnię obszaru zasilania, po przekroczeniu którego generowany był skoncentrowany spływ powierzchniowy (tab. 1). Dla obszarów leśnych przyjęto wartość 2 ha korzystając z badań E. Płaczkowskiej i innych (2015).

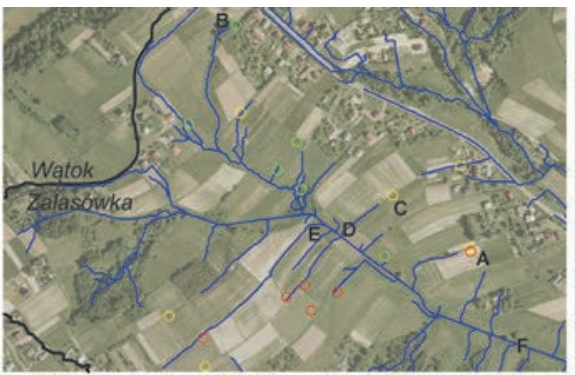

zarejestrowany początek odplywu skoncentrowanego na: head channel registered at:

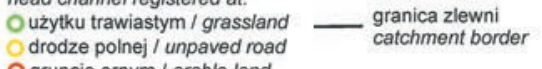

drodze polnej / unpaved road
O gruncie ornym / arable land
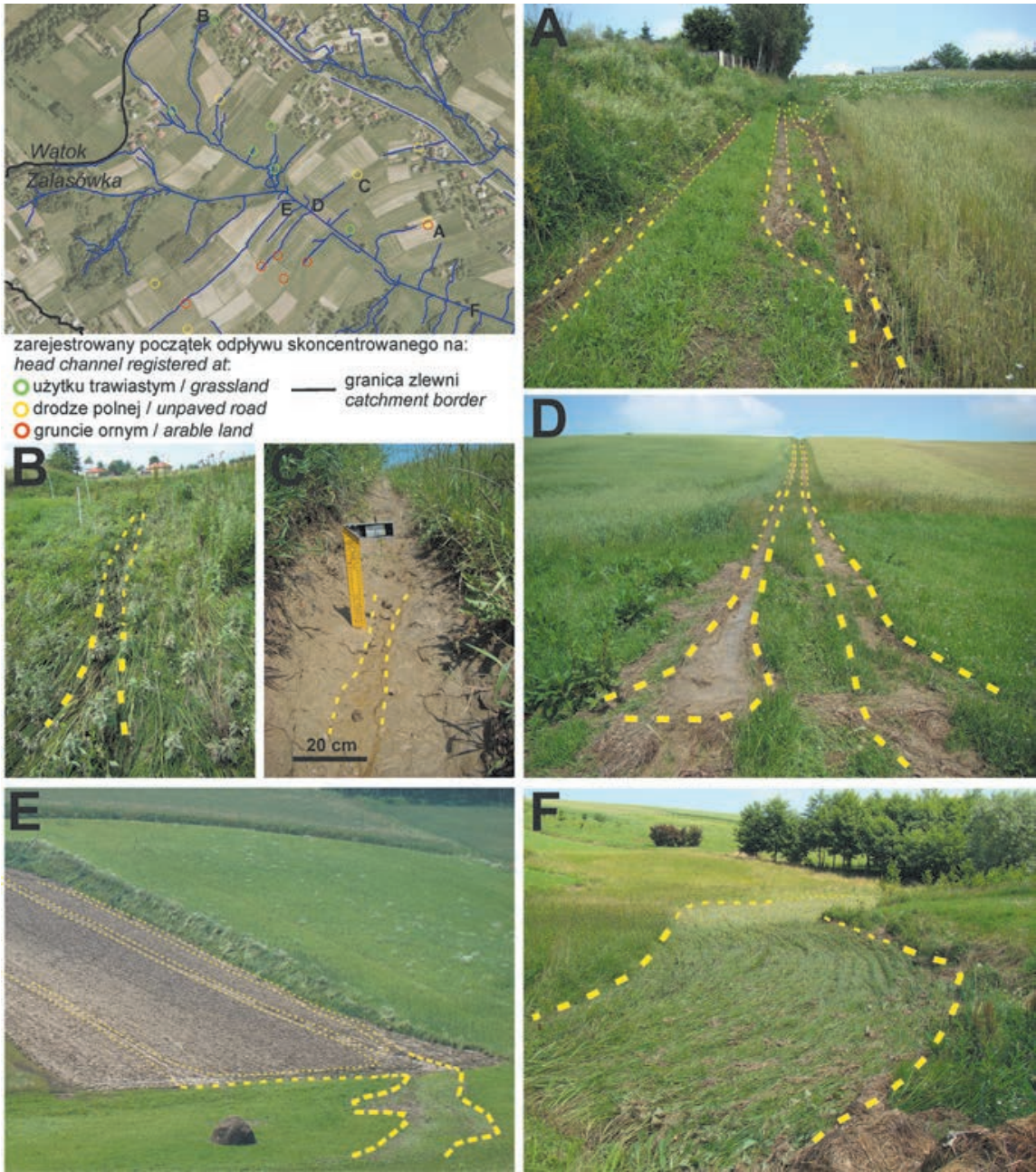

Ryc. 4. Miejsca zarejestrowanego spływu skoncentrowanego po nawalnym opadzie, który wystąpił 26/27 czerwca 2009

Places in which concentrated flow was generated after heavy rainfall on 26/27 June 2009 
Sieć drenażu wygenerowanego z NMT (z danych ALS) zoptymalizowano zgodnie z zaproponowaną w pracy procedurą. Aby ocenić różnice pomiędzy systemem rzecznym, który funkcjonuje w zlewni przez cały rok, system drenażu powierzchniowego wygenerowany z NMT porównano z siecią rzek znaczoną na mapie topograficznej w skali 1:10 000. W porównaniach posłużono się wskaźnikiem gęstości sieci $\left(\mathrm{km} \cdot \mathrm{km}^{-2}\right)$ oraz wskaźnikami ilościowymi wchodzącymi w skład tzw. analizy hortonowskiej (Horton, 1945; Schumm, 1956) z uwzględnieniem klasyfikacji cieków wg Strahlera (1957).

Porównanie tych systemów prezentuje rycina 5. Widać znaczne różnice w obu systemach. System rzeczny (ryc. 5A) ma gęstość $1,5 \mathrm{~km} \cdot \mathrm{km}^{-2}$ i jest rozwinięty do cieków 3 rzędu (tab. 2). System drenażu powierzchniowego jest bardziej rozbudowany. Gęstość tego systemu wynosi $13,7 \mathrm{~km} \cdot \mathrm{km}^{-2}$ i jest ona 9 razy większa od gęstości sieci rzecznej. Następuje również zmiana w układzie ogniw systemu. Cieki pierwszego rzędu stanowią drogi, rowy i bruzdy, czyli antropogeniczne elementy funkcjonujące na stoku podczas opadów nawalnych (ryc. 6A-H). Wzra-

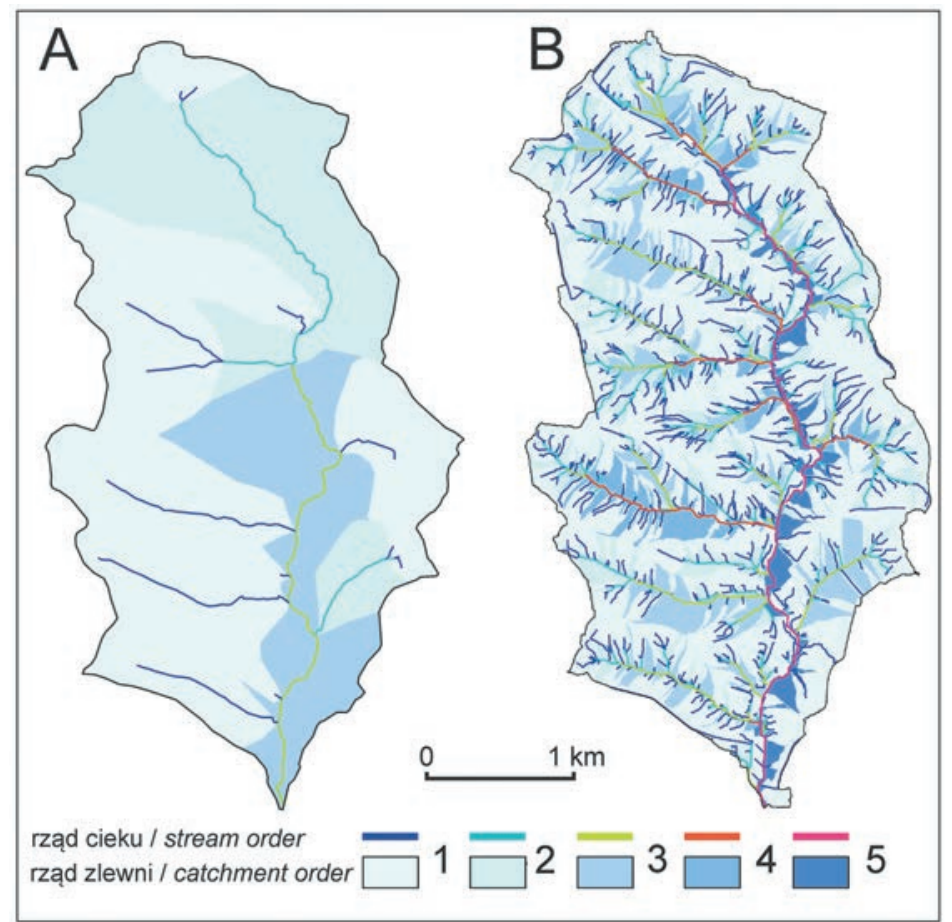

Ryc. 5. Sieć drenażu powierzchniowego z uwzględnieniem klasyfikacji cieków wg Strahlera

(1957). Wygenerowana dla mapy w skali 1:10 000 - A, wygenerowana z NMT - B

The surface drainage system classified in line with the system for the classification of watercourses after Strahler (1957). Generated on the basis of a 1:10 000 topo-map - A, generated on the basis of the DTM - B 
Tabela 2. Statystyka cieków w tzw. analizie hortonowskiej dla systemów drenażu powierzchniowego z mapy topograficznej i NMT z danych LiDAR z ALS

Statistics of a stream in hortonian type of analysis for surface drainage systems generated from topographic map and DTM from LiDAR (ALS)

\begin{tabular}{|c|c|c|c|c|c|c|}
\hline \multirow{2}{*}{$\begin{array}{l}\text { Rząd } \\
\text { cieku } \\
\text { Stream } \\
\text { order }\end{array}$} & \multicolumn{2}{|c|}{$\begin{array}{c}\text { Liczba cieków } \\
\text { Number of streams } \\
\text { (n) }\end{array}$} & \multicolumn{2}{|c|}{$\begin{array}{c}\text { Średnia długość cieków } \\
\text { Mean stream length } \\
(\mathrm{km})\end{array}$} & \multicolumn{2}{|c|}{$\begin{array}{c}\text { Średnia powierzchnia } \\
\text { zlewni } \\
\text { Mean catchment area } \\
\left(\mathrm{km}^{2}\right)\end{array}$} \\
\hline & $\begin{array}{l}\text { mapa topo- } \\
\text { graficzna } \\
1: 10000\end{array}$ & $\begin{array}{l}\text { NMT } \\
\text { (LiDAR } \\
\text { z ALS) }\end{array}$ & $\begin{array}{c}\text { mapa topo- } \\
\text { graficzna } \\
1: 10000\end{array}$ & $\begin{array}{l}\text { NMT } \\
\text { (LiDAR } \\
\text { z ALS) }\end{array}$ & $\begin{array}{l}\text { mapa topo- } \\
\text { graficzna } \\
1: 10000\end{array}$ & $\begin{array}{l}\text { NMT } \\
(\text { LiDAR } \\
\text { z ALS) }\end{array}$ \\
\hline 1 & 14 & 779 & 0,47 & 0,10 & 0,33 & 0,01 \\
\hline 2 & 3 & 182 & 1,26 & 0,23 & 2,49 & 0,04 \\
\hline 3 & 1 & 42 & 3,66 & 0,55 & 9,19 & 0,20 \\
\hline 4 & & 10 & & 1,15 & & 0,89 \\
\hline 5 & & 1 & & 7,24 & & 9,28 \\
\hline & $R_{B}=3,8$ & $R_{B}=5,7$ & $R_{L}=2,8$ & $R_{L}=3,3$ & $R_{A}=5,6$ & $R_{A}=6,0$ \\
\hline
\end{tabular}

$R_{B}, R_{L}, R_{A}-$ wskaźniki bifurkacji, średniej długości cieku, średniej powierzchni zlewni. Obliczenia własne.

$R_{B}, R_{L}, R_{A}$ - the bifurcation ratio, the mean length ratio, the mean area ratio. Source: authors.

sta o dwa rzędy wartość cieku najwyższego rzędu (z 3 do 5) oraz liczba cieków każdego rzędu (tab. 2). Znacznie zmniejsza się średnia długość oraz średnia powierzchnia cieków każdego rzędu, wzrastają wartości wskaźników bifurkacji $R_{B}$ z 3,8 do 5,7, średniej długości cieków $R_{L}$ z 2,8 do 3,3 oraz średniej powierzchni $R_{A}$ z 5,6 do 6,0 (tab. 2).

\section{Podsumowanie i wnioski}

W badaniach nad mechanizmami formowania powodzi błyskawicznych istotna jest informacja o parametrach systemu drenażu powierzchniowego. System ten odgrywa znaczącą rolę $\mathrm{w}$ formowaniu tego typu powodzi. $\mathrm{W}$ artykule podjęto próbę odpowiedzi na pytanie, jak wygląda system drenażu powierzchniowego, który funkcjonuje podczas opadów nawalnych w małej zlewni karpackiej. Jest to zagadnienie słabo poznane. Odpowiedź na to pytanie wymagała opracowania metodycznych podstaw związanych z doborem NMT, jego optymalizacją, doborem algorytmu generowania systemu drenażu powierzchniowego, włączając w to ustalenie wartości progowych, po przekroczeniu których formuje się pierwsze ogniwo systemu. Całość badań można podsumować formując kilka wniosków o różnej randze. 

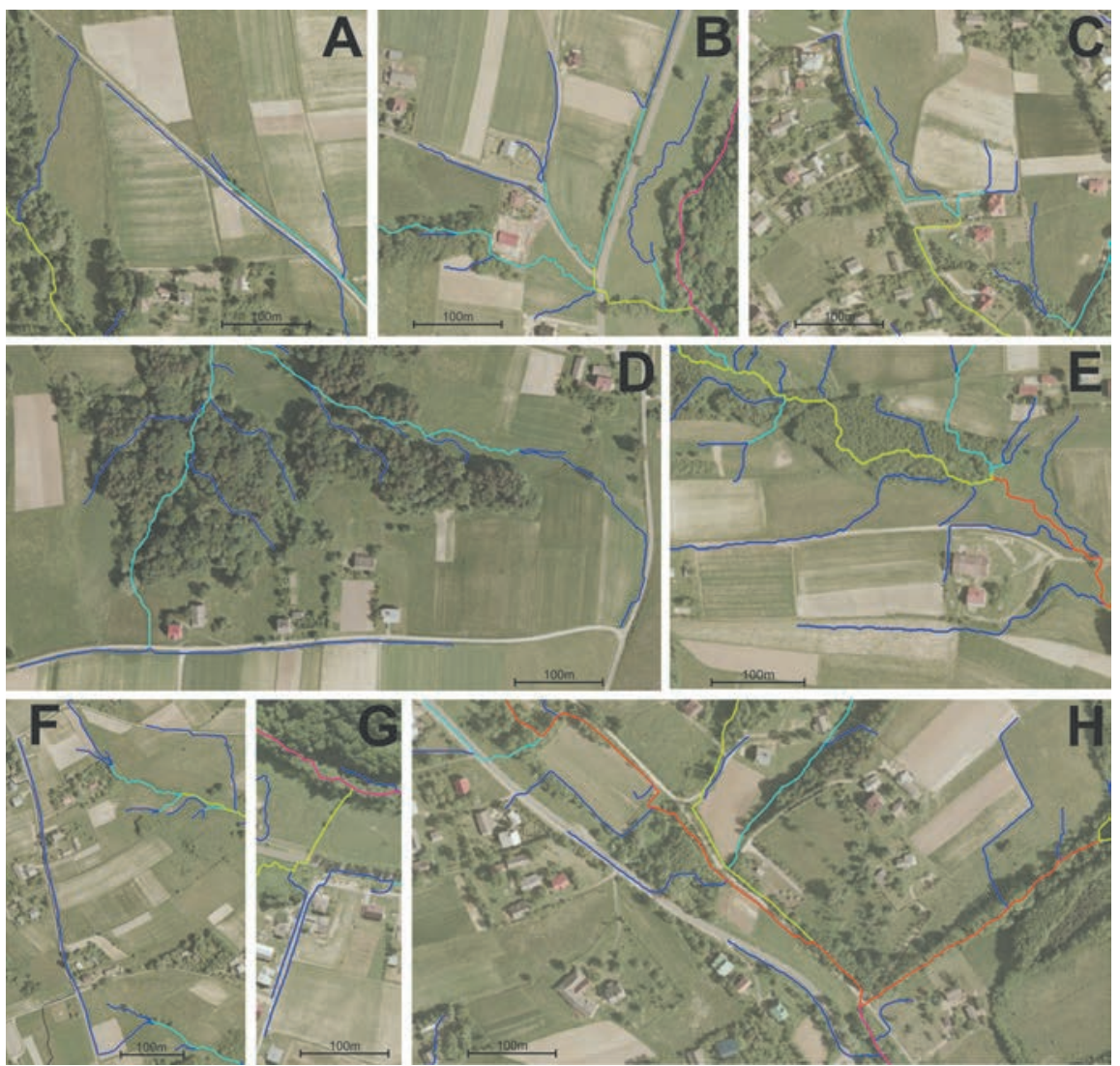

Ryc. 6. Linie spływu skoncentrowanego wygenerowane z NMT dla opadu z 26/27 czerwca 2009 r. (kolory rzędów cieków jak na rycinie 5)

Paths of concentrated flow on the basis of the DTM, for the rainfall of 26/27 June 2009 (colours of stream order correspond to those in Fig. 5)

1. Ogólnodostępne NMT o zasięgu globalnym można z powodzeniem stosować do generowania systemów drenażu powierzchniowego pochodzenia naturalnego tj. sieć dolin w zlewniach o powierzchni kilkuset $\mathrm{km}^{2}$ i większych. System drenażu powierzchniowego, w którym będą uwzględnione elementy powstałe w wyniku antropogenicznej działalności człowieka tj. drogi, rowy, bruzdy polne można wyznaczyć na podstawie NMT generowanych z danych LiDAR pochodzących z lotniczego skaningu laserowego ALS. Jest to obecnie najlepszy materiał wejściowy do tego typu analiz.

2. „Surowy” NMT pochodzący z danych LiDAR przedstawia zapis „rzeczywistej powierzchni gruntu”. W takiej formie zawiera on „przeszkody” w postaci mostów, przepustów oraz innych elementów, które powodują, że system 
drenażu powierzchniowego, wygenerowany na podstawie takiego NMT nie jest zgodny z tym, który funkcjonuje w rzeczywistości. Dlatego, opracowano i zaproponowano metodyczne podstawy procedury optymalizacji NMT. Według wiedzy autorów, jest to jedna z nielicznych tego rodzaju propozycji prezentowanych w literaturze.

3. Badania wykazały że algorytm D8, powszechnie stosowany w modułach do analiz hydrologicznych oprogramowania GIS, daje dobre rezultaty przy generowaniu systemu drenażu powierzchniowego w małych zlewniach karpackich. Algorytm ten, w połączeniu z opracowanymi wartościami progowymi, pozwala odwzorować linie spływu na drogach, rowach i użytkach rolnych ( $\mathrm{tj}$. bruzdy, rzędy upraw i inne regularne ślady działań agrotechnicznych).

4. Podczas opadów nawalnych funkcjonuje bardzo dobrze rozwinięty system drenażu powierzchniowego. Wskaźniki gęstości wskazują, że podczas opadów nawalnych system drenażu jest 9 razy lepiej rozwinięty $\left(13,7 \mathrm{~km} \cdot \mathrm{km}^{-2}\right)$ w porównaniu z systemem rzecznym $\left(1,5 \mathrm{~km} \cdot \mathrm{km}^{-2}\right)$ funkcjonującym przez cały rok. Podczas opadów nawalnych następują również zmiany jakościowe w systemie drenażu polegające na tym, że antropogeniczne elementy (drogi, rowy i bruzdy) są włączane do naturalnego systemu drenażu (rzek i dolin) i funkcjonują jako cieki pierwszego rzędu. Zmiany te mają odzwierciedlenie w tzw. parametrach hortonowskich. Znacznie zmniejsza się średnia długość oraz średnia powierzchnia cieków każdego rzędu, a wzrastają wartości wskaźników bifurkacji $R_{B}$, średniej długości cieków $R_{L}$ i średniej powierzchni $R_{A}$.

W pracy zaprezentowano wstępne wyniki badań. Autorzy planują je kontynuować w innych zlewniach. Dane LiDAR-owe oraz zaproponowana metodyka badań powinna pomóc lepiej poznać rozmiary i funkcjonowanie systemu drenażu powierzchniowego $\mathrm{w}$ warunkach ekstremalnych, czyli podczas silnych opadów deszczu.

\section{Piśmiennictwo / References}

Affek A., 2014, Lotnicze skanowanie laserowe (ALS) w modelowaniu rzeźby terenu - nowe możliwości i putapki, Problemy Ekologii Krajobrazu, 38, s. 217-236.

Bryndal T., 2014, Identyfikacja matych zlewni podatnych na formowanie gwattownych wezbrań w Karpatach polskich, Prace Monograficzne Uniwersytetu Pedagogicznego, 690, Kraków.

Bryndal T., Cabaj W., Gębica P., Kroczak R., 2010, Gwattowne wezbrania spowodowane nawalnymi opadami deszczu w zlewni potoku Wątok (Pogórze Ciężkowickie), [w:] T. Ciupa, R. Suligowski (red.), Woda w badaniach geograficznych, Instytut Geografii Uniwersytet Jana Kochanowskiego, Kielce, s. 307-319.

Bucała A., 2012, Wspótczesne zmiany środowiska przyrodniczego dolin potoków Jaszcze $i$ Jamne w Gorcach, Prace Geograficzne, IGiPZ PAN, 231, Warszawa.

Cebulski J., 2015, Naziemny skaning laserowy jako narzędzie do określenia aktywności osuwiska, Prace Studenckiego Koła Naukowego Geografów Uniwersytetu Pedagogicznego w Krakowie, 4, s. 12-20. 
Chavan S, Srinivas V., 2015, Effect of DEM source on equivalent Horton-Strahler ratio based GIUH for catchments in two Indian river basins, Journal of Hydrology, 528, s. 463-489.

Gil E., 1998, Sptyw wody i procesy geomorfologiczne w zlewniach fliszowych podczas gwattownej ulewy w Szymbarku w dniu 7 czerwca 1985 roku, Dokumentacja Geograficzna, 11, s. 85-107.

Gudowicz, J., 2008, Metoda modelowania zasięgu wód wezbraniowych na równinie zalewowej na przyktadzie doliny Parsęty, Landform Analysis, 8, 29-32.

Hengl T., Reuter H.I. (red.), 2008, Geomorphometry: Concepts, Software, Applications, Elsevier, Amsterdam.

Horton, R. E., 1945, Erosional development of streams and their drainage basins; hydrophysical approach to quantitative morphology, Geological Society of America Bulletin, 56, 3, s. 275-370.

Jasiewicz J., 2010, Analiza topologiczna sieci drenażu w programie GRASS, [w:] Z. Zwoliński (red.), GIS - woda w środowisku, Bogucki Wydawnictwo Naukowe, Poznań, s. 87-119.

Jaskulski M., Szmidt A., 2015, Transformations in morphometry of valley bottom as a result of the creation of a reservoir illustrated with the example of Sulejów Lake, Landform Analysis, 27, s. 15-21.

Julian J.P., Elmore A.J., Guinn S.M., 2012, Channel head locations in forested watersheds across the mid-Atlantic United States: a physiographic analysis, Geomorphology, 177-178, s. 194-203.

Kroczak R., 2010, Geomorfologiczne i hydrologiczne skutki funkcjonowania dróg polnych na Pogórzu Ciężkowickim, Prace Geograficzne, IGiPZ PAN, 225, Warszawa.

Kroczak R., Bryndal T., 2015, An attempt to assess the influence of road network on flash flood wave parameters. The case study of the Carpathian Foothills, [w:] Z. Jasiewicz, Z. Zwoliński, H. Mitasova, T. Hengl (red.), Geomorphometry for Geosciences, Adam Mickiewicz University in Poznań, Institute of Geoecology and Geoinformation, International Society for Geomorphometry, Poznań, s. 197-200.

Kroczak R., Bryndal T., Bucała A., Fidelus J., 2016, The development, evolution and environmental influence of an unpaved road network on mountain terrain - an example from the Carpathian Mts. (Poland), Environmental Earth Sciences, 75, 3, s. 1-14.

Kurczyński Z., Bakuła K., 2013, Generowanie referencyjnego numerycznego modelu terenu o zasiegu krajowym w oparciu o lotnicze skanowanie laserowe w projekcie ISOK, Archiwum Fotogrametrii, Kartografii i Teledetekcji, wydanie specjalne: Monografia Geodezyjne Technologie Pomiarowe, s. 59-68.

Lorenc H., Cebulak E., Głowicki B., Kowalewski M., 2012, Struktura i występowanie intensywnych opadów deszczu powodujących zagrożenie dla społeczeństwa, środowiska i gospodarki Polski, [w:] H. Lorenc (red.), Wptyw zmian klimatu na środowisko, gospodarkę $i$ społeczeństwo. Tom 3., Klęski żywiołowe a bezpieczeństwo wewnętrzne kraju, IMGW-PIB, Warszawa, s. 7-32.

Moore I.D., Grayson R.B., Ladson A.R., 1991, Digital terrain modelling: a review of hydrological, geomorphological, and biological applications, Hydrological Processes, 5, 1, s. 3-30.

O'Callaghan J.F., Mark D.M., 1984, The extraction of drainage networks from digital elevation data, Computer Vision, Graphics, and Image Processing, 28, 3, s. 323-344.

Olszewski R., Berezowski T., Świtaj K., 2008, System zarządzania danymi wysokościowymi LPIS, TBD $i$ SMOK zgromadzonymi w PZGiK, Roczniki Geomatyki, 6, 4, s. 83-88. 
Persendt F.C., Gomez C., 2015, Assessment of drainage network extractions in a low-relief area of the Cuvelai Basin (Namibia) from multiple sources: LiDAR, topographic maps, and digital aerial orthophotographs, Geomorphology, 260, s. 32-50.

Płaczkowska E., Górnik M., Mocior E., Peek B., Potoniec P., Rzonca B., Siwek J., 2015, Spatial distribution of channel heads in the Polish Flysch Carpathians, Catena, 127, s. 240-249.

Prokop P., 2007, Degradacja środowiska przyrodniczego potudniowego skłonu Wyżyny Meghalaya, Indie, Prace Geograficzne, IGiPZ PAN, 210, Warszawa.

Przybyła C., Pyszny K., 2013, Porównanie numerycznych modeli terenu SRTM i ASTER GDEM oraz ocena możliwości ich wykorzystania w modelowaniu hydrologicznym w obszarach o matych deniwelacjach, Rocznik Ochrona Środowiska, 15, s. 1489-1510.

Pyka K., 1994, Opracowanie cyfrowego modelu terenu dla części województwa krakowskiego, Archiwum Fotogrametrii Kartografii i Teledetekcji, 2, s. 40-49.

Schumm S.A., 1956, Evolution of drainage systems and slopes in badlands and Perth Amboy, NJ, Geological Society of America Bulletin, 67, s. 597-646.

Soja R., 2002, Hydrologiczne aspekty antropopresji w polskich Karpatach, Prace Geograficzne, IGiPZ PAN, 186, Warszawa.

Strahler A.N., 1957, Quantitative analysis of watershed geomorphology, Transactions of American Geophysical Union, 38, 6, s. 913-920.

Śleszyński P., 2009, Wykorzystanie danych georadarowych SRTM-3 w analizie zróżnicowania uksztattowania terenu Polski, Polski Przegląd Kartograficzny, 41, 3, s. 237-25.

Turcotte R., Fortin J.P., Rousseau A.N., Massicotte S., Villeneuve J.P., 2001, Determination of the drainage structure of a watershed using a digital elevation model and a digital river and lake network, Journal of Hydrology, 240, 3-4, s. 225-242.

Urbański J., 2008, GIS w badaniach przyrodniczych, Wydawnictwo Uniwersytetu Gdańskiego, Gdańsk.

Wałek G., 2013, Wykorzystanie programów Quantum GIS i SAGA GIS do budowy cyfrowego modelu wysokościowego zlewni Grajcarka, Acta Universitatis Lodziensis, Folia Geographica Socio-Oeconomica, 14, s. 133-144.

Wężyk P., Szostak M., Rysiak P., Zięba K., Hawryło P., Ratajczak M., 2015, Dąb Bartek 3D - naziemne skanowanie laserowe 3D pomników przyrody - nowy wymiar edukacji przyrodniczej, Studia i Materiały Centrum Edukacji Przyrodniczo-Leśnej, 17, 2 (43), s. $7-15$.

Wiejaczka Ł., Kroczak R., Kijowska-Strugała M., 2012, Methods for the assessment of changes in the bottom morphology of a mountain reservoir, Studia Geomorphologica Carpatho-Balcanica, 46, 1, s. 41-50.

Witek M., Jeziorska J., Niedzielski T., 2013, Możliwości wykorzystania bezzałogowej fotogrametrii lotniczej do identyfikacji przeksztatcen antropogenicznych w korytach rzecznych, Landform Analysis, 24, s. 115-126.

[Wpłynęło: lipiec; poprawiono: listopad 2016 r.] 
RAFAŁ KROCZAK, TOMASZ BRYNDAL

\section{USE OF DIGITAL TERRAIN MODELS TO GENERATE THE SURFACE DRAINAGE NETWORK FUNCTIONING DURING HEAVY RAINFALL \\ Methodological aspects based on the Zalasówka catchment (Ciężkowickie foothills)}

In considering the process by which flash floods form, core information concerns the parameters of an area's surface drainage system. That system is composed of elements of natural origin (rivers and valleys), as well as those of an anthropogenic nature (roads, ditches and rills), which together operate as a single drainage system at times of heavy rainfall. In line with this understanding, the work underpinning this article has focused on: 1) a characterisation of different types of DTM in the context of their application to detailed surface drainage system generation in small Carpathian catchments, 2) methodological aspects of DTM modification allowing elements of anthropogenic origin, such as roads, ditches and rills to be included within the surface drainage system, 3) a characterisation of the differences between the river system operating year-round and the surface drainage system functioning at times of heavy rainfall.

The results reveal that the most popular DTMs, such as the SRTM, ASTER, TBD and SMOK, do not allow detailed surface drainage systems (including anthropogenic origin elements such as roads, ditches, etc.) to be generated. Such a goal may be achieved by analysis of a DTM generated on the basis of LiDAR (Light Detection And Ranging) data. However, such a DTM includes certain "obstacles" (bridges, culverts, etc.) that modify real concentrated flow paths. A methodology for LIDAR-type DTM modification was therefore proposed, with this including: 1) selection and digitisation (as line-type vector data) of the said "obstacles" (on the basis of field data and analyses of aerial photographs), 2) characterisation of the vectors ("obstacles") by reference to the four attributes of buffer, incision, channel and resolution) - Fig. 2, and 3) modification of the DTM through burning of the "obstacles" using the attributes mentioned above. Such an approach allows for the generation of a surface drainage system similar to that observed in the terrain. The surface drainage system in question was generated using the D8 algorithm, with the threshold values required for first-order stream generation being calculated on the basis of field studies following on from a rainfall event (26/2706-2009). The methodology proposed in this study seems to be correct. The surface drainage system generated on the basis of the DTM in the Zalasówka catchment was composed of elements of anthropogenic and natural origin, and was comparable with the system operating at the time of the rainfall event examined.

The results for the period of heavy rainfall revealed a surface drainage system 9 times more developed (at $13.7 \mathrm{~km} \cdot \mathrm{km}^{-2}$ ) than the river system $\left(1.5 \mathrm{~km} \cdot \mathrm{km}^{-2}\right)$. There were significant changes in the stream pattern reflected in the Horton and Schumm ratios. There was also increases in the maximum stream order, the bifurcation ratio $R_{B}$, the length ratio $R_{L}$ and the area ratio $R_{A}$; as well as a decrease in the mean length and mean area of the first-order stream.

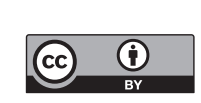


http://rcin.org.pl 